\title{
Lower lip reconstruction with nasolabial flap - going back to basics*
}

\author{
Inês Coutinho ${ }^{1}$ \\ Ana Rita Gameiro ${ }^{1}$ \\ Américo Figueiredo ${ }^{1}$
}

\author{
Leonor Ramos ${ }^{1}$ \\ Ricardo Vieira ${ }^{1}$
}

DOI: http:/ /dx.doi.org/10.1590/abd1806-4841.20153714

\begin{abstract}
A bstract: Squamous cell carcinoma of the lower lip is frequent, and radical excision sometimes leads to complex defects. Many lip repair techniques are aggressive requiring general anesthesia and a prolonged post-operative period. The nasolabial flap, while a common flap for the repair of other facial defects, is an under-recognized option for the reconstruction of the lower lip. We describe the use of nasolabial flap for the repair of a large defect of the lower lip in a ninety year-old male, with good functional results and acceptable cosmetic outcome. We believe the nasolabial flap is a good alternative for intermediate-to-large lower lip defects in patients with impaired general condition.
\end{abstract}

Keywords: Carcinoma, squamous cell; Lip; Lip neoplasms; Neoplasms, squamous cell; Surgical flaps

\section{INIRODUCTION}

Lips are used daily in social interaction and feeding and represent the most striking feature of the lower third of the face. The lower lip is the preferred location for squamous cell carcinomas (SCC), due mainly to UV exposure. ${ }^{1}$ Other predisposing factors include tobacco use, HPV infection and immunosuppression. ${ }^{1}$

Surgical excision, the mainstay of therapy, often results in large defects with volumetric and topographic complexity. ${ }^{2}$

Most techniques for lip repair were developed during the 19th century, having evolved since then. The abundance of classical flap variations (such as Karapandzic, Bernard-Burrow-Webster and AbbéEstlander) reflects the overall inadequacy to suit every single patient with any given defect. ${ }^{3,4}$
Thus, adjustment of existing options to the surgical defect and to the patient's comorbidities is necessary. We report a case using the nasolabial flap, an under-recognized option for the reconstruction of the lower lip.

\section{CASE REPORT}

A 93-year old male, with valvular heart disease and history of a cerebrovascular accident, presented with a $5 \mathrm{~cm}$ ulcerated exophytic tumor occupying $80 \%$ of the lower lip, extending to the mucosa (Figure1). It had been evolving for a year and there were no palpable regional lymph nodes. Incisional biopsy confirmed SCC.

Radical excision resulted in a full-thickness defect of nearly $90 \%$ of the lower lip. We designed a banner-shaped inferiorly based flap, $3,5 \mathrm{~cm}$ wide

Approved by the Advisory Board and accepted for publication on 07.07.2014.

Work performed at the Centro Hospitalar Universitário de Coimbra - Coimbra, Portugal.

Financial Support: None.

Conflict of Interest: None.

1 Coimbra University Hospital - Coimbra, Portugal.

(2015 by Anais Brasileiros de Dermatologia 


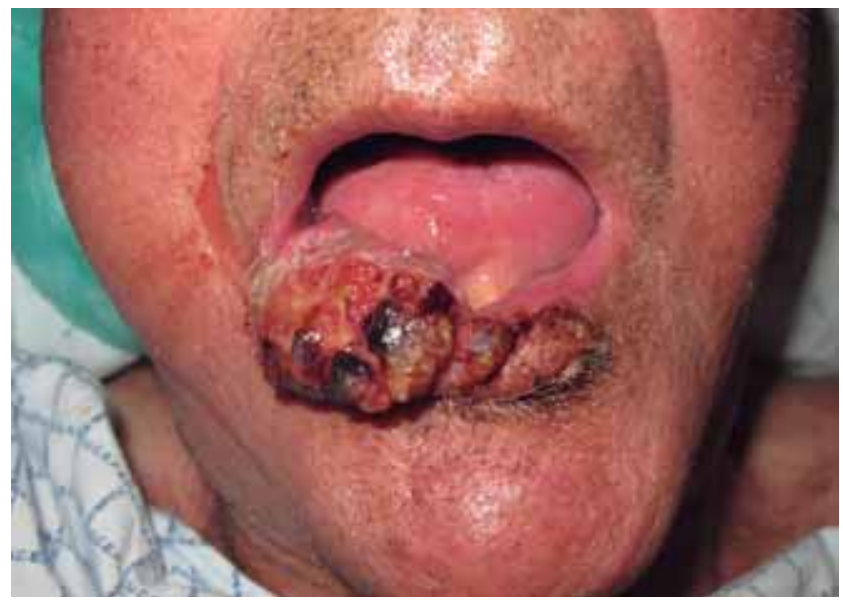

Figure 1: Squamous cell carcinoma occupying nearly $90 \%$ of the lower lip and extending to the mucosa

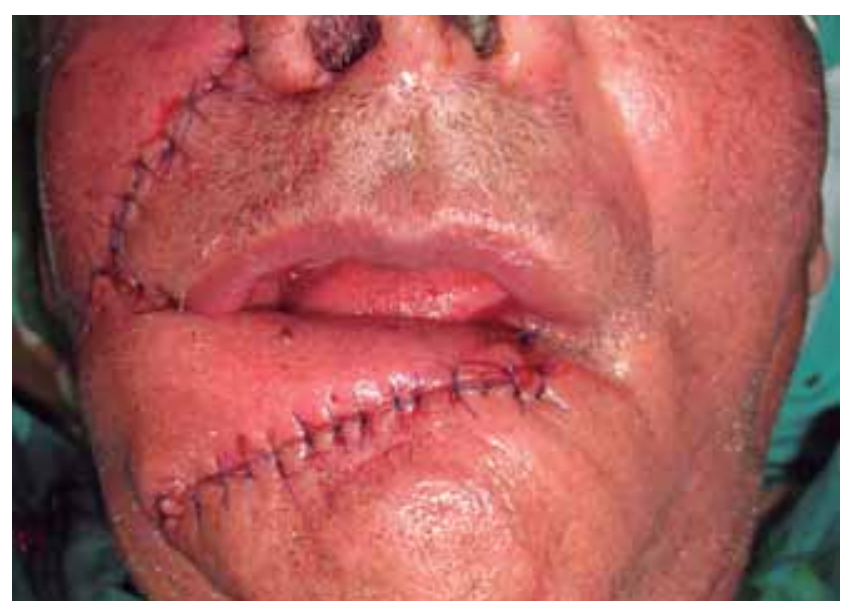

FIGURE 2: Immediate post-operative result

and $8 \mathrm{~cm}$ long, following the nasolabial crease. To minimize creation of dog-ears and suspend the flap, its base was done superiorly and laterally to the commissure. It was raised above the superficial muscular aponeurotic system, from top to bottom, and transposed transversely to fill the defect. The donor site was closed primarily to better adjust the flap to the defect, and the latter was sutured directly (Figure 2). The mucosal lining was then advanced to reconstruct the inner vermillion.

During the post-op period a hematoma developed at the donor-site region that required draining and healed by second intention. There was slight liquid incontinence at the oral commissure, not considered functionally significant, with a satisfactory cosmetic result (Figure 3).

The patient was followed for 9 months, without local or regional recurrence but was later lost to follow-up.

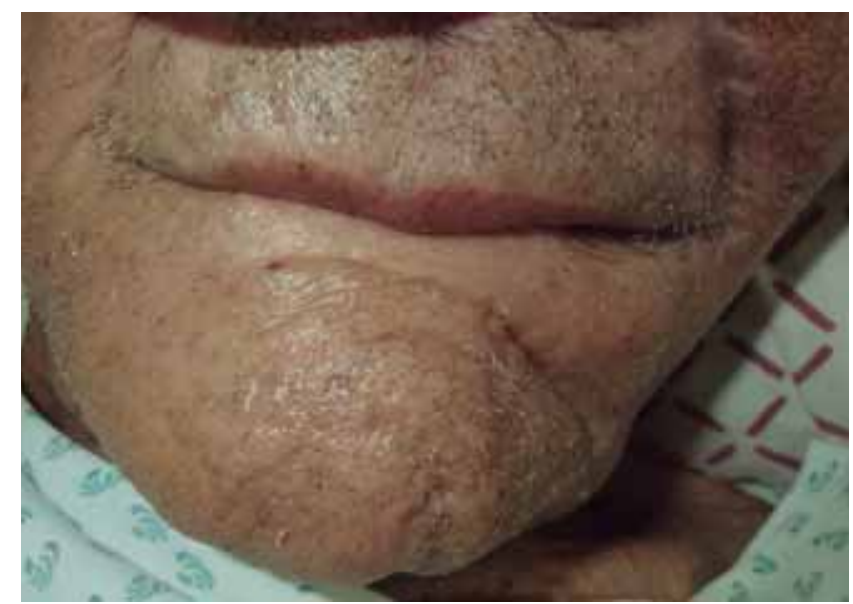

FIgURE 3: Nine months after surgery, with reasonable functional and cosmetic result

\section{DISAUSSION}

The nasolabial flap is widely used in facial reconstruction, due to its accessibility, reliability, and because it's easy to master. ${ }^{5}$ Its use is well known for reconstruction of nasal, cheek and lower eyelid defects.

First described by Von Bruns, in 1857, it can be used for the repair of the entire lower lip, using either unilateral or bilateral flaps. A triangle with an inferior base is drawn along the nasolabial crease, then dissected above the superficial muscular aponeurotic system and transposed to the defect. The flap's rich subdermal plexus confers viability even allowing for a length-base relation of 3:1. 6,7 Its base should ideally measure from 2,5 up to $3,5 \mathrm{~cm}$, gathered that surrounding tissue has enough laxity. The main concern regarding the length is the possibility of ectropion, warranting caution when the tip of the flap is drawn too close to the lower eyelid.

Most lip reconstruction techniques are aggressive; require general anesthesia and prolonged post-op time. Some may even require a second surgical intervention. ${ }^{3}$ The nasolabial flap, despite being an adynamic repair, since it interrupts the orbicularis oris, represents a good option for attaining a "sling" effect, while permitting good oral opening for dental hygiene, feeding and speech. 8,9 Moreover, donor-tissue morbidity is significantly reduced (as are duration of surgery and recovery time), when opposed to Karapandzic or Bernard-Burrow-Webster flaps, making it preferable in patients with impaired general condition.

The authors believe that the nasolabial flap constitutes a simple, effective and safe alternative for repairing intermediate-to-large defects of the lower lip in the elderly. $\square$ 


\section{REFERENCES}

1. Andrade P, Brites MM, Vieira R, Mariano A, Reis JP, Tellechea 0, et al. Epidemiology of basal cell carcinomas and squamous cell carcinomas in a Department of Dermatology - a 5 year review. An Bras Dermatol. 2012;87:212-9.

2. Scully C, Bagan JV. Recent advances in oral oncology: squamous cell carcinoma imaging, treatment, prognostication and treatment outcomes. Oral Oncol. 2009;45:e25-30.

3. Baumann D, Robb G. Lip Reconstruction. Semin Plast Surg. 2008;22:269-80.

4. Aldelaimi TN, Khalil AA. Lip reconstruction using Karapandzic flap. J Craniofac Surg. 2014;25:e136-8.

5. Zhang Y, Wu HL, Lu YM.Contralateral Nasolabial Flap for Reconstruction of Midface Defects. Aesthetic Plast Surg. 2012;36:1175-8.

6. Rudkin GH, Carlsen BT, Miller TA. Nasolabial Flap Reconstruction of Large Defects of the Lower Lip. Plast Reconstr Surg. 2003;111:810-7.

7. Singh S, Singh RK, Pandey M. Nasolabial flap reconstruction in oral cancer. World J Surg Oncol. 2012;10:227.

8. Varghese BT, Sebastian P, Cherian T, Mohan PM, Ahmed I, Koshy CM, et al. Nasolabial flaps in oral reconstruction: an analysis of 224 cases. Br J Plast Surg. 2001;54:499-503.

9. Chitlangia P, Kumuran E, Sabitha KS. Use of nasolabial flap in intra and extraoral reconstruction: our experience with 40 cases. J Maxillofac Oral Surg. 2012;11:451-4.
M AILING ADDRESS:

M aria Inês Sampaio D antas Coutinho

Serviço de D ermatologia

Centro H ospitalar e U niversitário de Coimbra

A venida Bissaya Barreto

Praceta Prof. M ota Pinto

3000 - Coimbra

Portugal

E-mail: inesdantascoutinho@gmail.com

H ow to cite this article Coutinho I, Ramos L, Gameiro AR, Vieira R, Figueiredo A. Lower lip reconstruction with nasolabial flap - going back to basics. An Bras Dermatol. 2015;90(3 Suppl 1):S206-8. 